\title{
REAKSI PASAR ATAS STOCK SPLIT PADA EMITEN SAHAM SYARIAH DI BURSA EFEK INDONESIA
}

$$
\text { PERIODE 2011-2014 11 }
$$

\author{
Aldila Vania Jasmine \\ Mahasiswa Program Studi S1 Ekonomi Islam - Fakultas Ekonomi dan Bisnis - Universitas \\ Airlangga \\ Email : aldilavj@yahoo.co.id
}

Leo Herlambang

Departemen Ekonomi Syariah - Fakultas Ekonomi dan Bisnis - Universitas Airlangga

Email : leo.herlambang@gmail.com

\begin{abstract}
:
The aims of this study are to identify and explain the market reaction as the result of corporate action in the form of stock split managed by the stock issuers registered with Jakarta Islamic Index and Indonesia Sharia Stock Index from period 2011 to 2014.

This study used quantitative approach with event study method. Those stock issuers also have to perform the stock split and have been registered with ISII and JII to fulfill the requirements of this study. While the focus of this study is the reaction indicated by the change of AAR and CAAR by doing several test such as one sample t-test and paired sample t-test by defining the level of significant in the amount of $5 \%$.

The results of the study indicate there is no significance difference in the AAR before and after the stock split, but there is a quite significance difference in the CAAR.

Keywords: Market Reaction, Stock Split, Stock Return, Average Abnormal Return, Cumulative Average Abnormal Return
\end{abstract}

\section{PENDAHULUAN}

Berinvestasi tidak semata-mata murni menjadi dorongan seseorang untuk ikut ambil bagian dalam permodalan perusahaan. Masih ada motif-motif lain yang mendasari dan menjadi alasan yang kuat. Motif seseorang melakukan investasi menurut Tandelilin (2001, dalam Husnan dan Nasution 2007:8) adalah:

a. Untuk mendapatkan kehidupan yang lebih layak di masa yang akan datang

b. Mengurangi tekanan inflasi

c. Sebagai usaha untuk menghemat pajak.

Telah disebutkan dengan jelas oleh Tandelilin pada butir pertama yaitu motif sesorang berinvestasi adalah untuk mendapatkan kehidupan yang lebih layak di masa yang akan datang karena dengan berinvestasi maka seseorang diharapkan akan mendapat keuntungan yang dapat menjadi salah satu sumber kekayaan. Chapra (2000:20) dalam bukunya menegaskan bahwa salah satu sumber penting peningkatan kekayaan yang tidak diperbolehkan adalah menerima keuntungan moneter dalam sebuah transaksi bisnis tanpa memberikan suatu imbalan setimpal yang adil.

Keadilan tidak hanya pada besar jumlah keuntungan yang dibagikan secara setara dan tidak berat sebelah, namun dengan cara-cara yang bebas dari kedzaliman. Allah SWT berfirman:

1) Jurnal ini merupakan bagian dari skripsi Aldila Vania Jasmine, NIM : 041014075, yang diuji pada 10 Agustus 2015. 


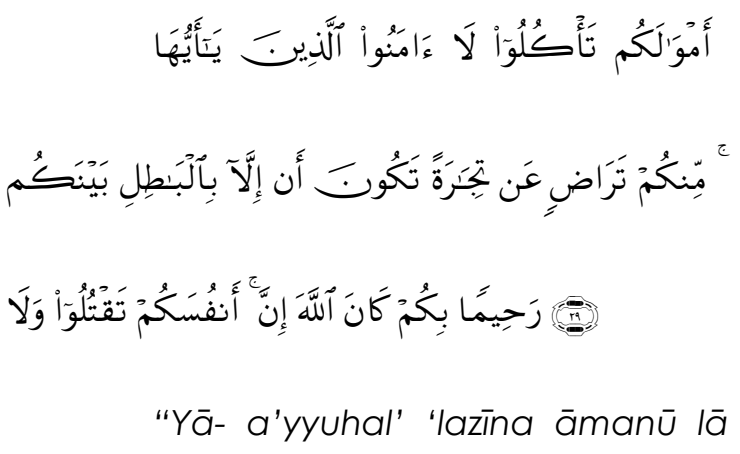

ta' kulū-amwa lakum-baynakum bilbāțili' illāan'takūnatijā 'rotan'antarroodinmihkum. Walātatulū'anfusakum. Innallahakāna bikum r'ohimaan".

"Hai orang-orang yang beriman, janganlah kamu saling memakan harta sesamamu dengan jalan yang batil, kecuali dengan jalan perniagaan yang Berlaku dengan suka sama-suka di antara kamu. dan janganlah kamu membunuh dirimu[287]; Sesungguhnya Allah adalah Maha Penyayang kepadamu". (Q.S. An Nisaa':29).

Sebagaimana disebutkan dalam surat An-Nisa' ayat 29 bahwa umat sesama manusia diperbolehkan untuk tolong-menolong lewat jalan perniagaan. Tujuan berniaga adalah mendapat manfaat dari apa yang dimiliki oleh pihak tertentu yang tidak ada pada diri kita dengan cara-cara yang tidak melanggar aturan agama maupun norma masyarakat. Hal penting yang harus dipatuhi pada kegiatan niaga menurut agama Islam adalah bahwa obyek niaga tersebut adalah barang atau jasa yang halal dan thayyib. Maka dari itu seorang investor muslim diharuskan berpedoman pada etika berinvestasi yang adil, dan wajib berinvestasi pada produk investasi yang halal.

Indonesia sebagai negara dengan jumlah umat muslim terbesar di dunia membutuhkan pasar saham yang ideal untuk bertransaksi saham secara syariah. Untuk memengakomodir kebutuhan tersebut dibentuklah pasar modal syariah .

Jual beli saham termasuk jual beli kepemilikan perusahaan yang telah diakomodir lewat bursa saham yang telah terdaftar di Otoritas Jasa Keuangan (OJK). Adanya pasar saham selain untuk memperluas pasar, adalah sebagai sarana untuk menambah nilai modal perusahaan sehingga dapat beroperasi dengan baik sesuai dengan tujuan perusahaannya.

Pasar saham Indonesia tidak lepas dari fenomena stock split, termasuk pasar saham yang menjadi obyek penelitian skripsi yaitu emiten saham syariah yang terdaftar di Jakarta Islamic Index (JII) di Indeks Saham Syariah Indonesia (ISSI). Semenjak tahun 2010 tercatat sebanyak 30 perusahaan publik melakukan stock split hingga rentang waktu tahun 2014.

Pengumuman stock split oleh perusahaan dianggap mengandung information content yang dapat mempengaruhi harga saham, dan sebagai investor yang rasional dan tanggap akan perubahan informasi tentu akan merespon setiap corporate action yang ada untuk menentukan keputusan investasi nya. 
Jogiyanto

(2009:537)

menerangkan ada hal yang dapat dicermati berkaitan dengan adanya reaksi terhadap corporate action, yaitu:

\section{Rumusan Masalah}

1. Apakah terdapat perbedaan pendapatan nilai Average Abnormal Return (AAR) pada emiten saham syariah yang terdaftar di Bursa Efek Indonesia pada periode 2011-2014 pasca pengumuman stock split?

2. Apakah terdapat perbedaan pendapatan nilai Cumulative Average Abnormal Return (CAAR) yang pada emiten saham syariah yang terdaftar di Bursa Efek Indonesia pada periode 2011-2014 pasca pengumuman stock split?

\section{Tujuan Penelitian}

1. Mengetahui perbedaan dari faktor stock split terhadap nilai Average Abnormal Return (AAR) emiten saham syariah yang terdaftar diBursa Efek Indonesia pada periode 2011-2014 pasca pengumuman stock split.

2. Mengetahui perbedaan dari faktor stock split terhadap nilai Cumulative Average Abnormal Return (CAAR) emite saham syariah yang terdaftar di Bursa Efek Indonesia periode 20112014

\section{LANDASAN TEORI}

Dalam Kamus Lengkap Ekonomi, investasi didefinisikan sebagai penukaran vang dengan bentuk-bentuk kekayaan lain seperti saham atau harta tidak bergerak yang diharapkan dapat ditahan
"Reaksi ini dapat diukur dengan menggunakan return sebagai nilai perubahan harga atau dengan menggunakan abnormal return. selama periode waktu tertentu supaya menghasilkan pendapatan (Wirasamita, 1999 dalam Huda dan Nasution, 2007:7).

Dalam sistem ekonomi konvensional, seseorang melakukan investasi dengan motif yang berbedabeda, di antaranya untuk memenuhi kebutuhan likuiditas, menabung agar mendapat pengembalian yang lebih besar, merencanakan pensiun, untuk berspekulasi dan lain-lain (Ryandono, 2009:68).

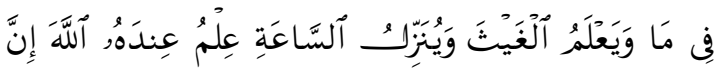

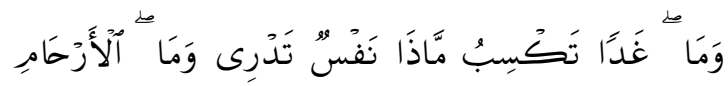

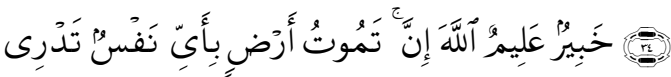

Inna-l'LāHa-'indaHu-'ilmu-ssā- 'atiwayunazzilu-Ighaitsa-waya'lamu-māfilarhāmi.Wa-mātdrī-nafsunmā'dzātaksibu'ghodān.Wamātadrī-nafrī-nafsaumbia-yyi-ardhin-tamūtu. Inna-l'Lāha'alimun-khobiru.

"Sesungguhnya Allah, hanya pada sisi-Nya sajalah pengetahuan tentang hari Kiamat; dan Dia-lah yang menurunkan hujan, dan mengetahui apa yang ada dalam rahim. dan tiada seorangpun yang dapat mengetahui (dengan pasti) apa yang akan diusahakannya besok. Dan tiada seorangpun yang dapat mengetahui di 
bumi mana Dia akan mati. Sesungguhnya Allah Maha mengetahui lagi Maha Mengenal".

Dari penggalan Q.S Al-Luqman dengan tegas dinyatakan bahwa Allah SWT telah mengatur semua urusan baik di bumi dan di langit untuk kebaikan manusia di dunia dan akhirat dan segala urusan adalah dalam pengawasan Allah SWT yang Maha Mengetahui baik hal yang tampak maupun hal yang tak tampak, padahal bias jadi perkara tersebut tidak diketahui secara pasti oleh manusia. Termasuk di dalamnya urusan perniagaan maupun bagaimana seorang hamba mencari harta tak lepas dari pengawasan Allah SWT.

\section{Jenis pasar modal}

Pasar modal dikategorikan berdasarkan empat macam yaitu pasar pertama (perdana), pasar kedua (sekunder), pasar ketiga dan pasar keempat.

Pasar perdana adalah tempat atau sarana bagi perusahaan yang untuk pertama kali menawarkan saham obligasi ke masyarakat umum. Sebelumnya perusahaan tersebut merupakan milik perseorangan atau beberapa orang dan kemudian ditawarkan kepada masyarakat umum yang kemudian disebut sebagai initial public offering (IPO)

Pasar kedua adalah tempat atau sarana transaksi jual beli efek antar investor dan harga dibentuk oleh investor melalui perantara efek antar investor dan harga dibentuk oleh investor melalui perantara efek. Penjamin efek dan calon pembeli tidak bertemu secara fisik namun melalui sistem perdagangan pada bursa efek.

Pasar ketiga adalah sarana transaksi jual beli efek antara market maker serta investor dan harga dibentuk oleh market maker. Investor dapat memilih market maker yang memberi harga terbaik. Market maker adalah anggota bursa. Para market maker ini akan bersaing dalam menentukan harga saham karena satu jenis saham dipasarkan oleh lebih dari satu market maker.

Pasar keempat adalah sarana transaksi jual beli antara investor beli tanpa melalui perantara efek. Transaksi dilakukan secara tatap muka antara investor beli dan investor jual untuk saham atas pembawa.

\section{Pasar Modal Syariah}

Definisi pasar modal sesuai dengan Undang-undang Nomor 8 Tahun 1995 tentang Pasar Modal (UUPM) adalah kegiatan yang bersangkutan dengan Penawaran Umum dan perdagangan Efek yang diterbitkannya, serta lembaga dan profesi yang berkaitan dengan Efek.

Berdasarkan definisi tersebut, terminologi pasar modal syariah dapat diartikan sebagai kegiatan dalam pasar modal sebagaimana diatur dalam UUPM yang tidak bertentangan dengan prinsip syariah (www.ojk.go.id).

Sementara menurut International Organization of Securities Commissions 
(IOSCO) seperti dikutip dari Fatimatuzzahra (2015:14) menyatakan bahwa:

"The emerge of distinct Islamic capital market where investment and financing activities and product are structured in accordance with shariah principles"

Dari penjelasan tersebut dapat disimpulkan bahwa investasi pada modal syariah telah diatur berdasarkan prinsip dan dijalankan menurut suatu kaidah tertentu yang sesuai dengan prinsip syariah

\section{Hukum Pasar Modal Syariah}

Jual beli saham pada prinsipnya merupakan sarana untuk mengumpulkan modal dengan mitra yang seluas-luasnya untuk mencapai tujuan operasional perusahaan melalui cara jual-beli. Jual beli tersebut telah diakomodir oleh bursa saham yang kredibel dan diawasi oleh Otoritas Jasa Kevangan (OJK). Pontjowinoto (2003:17) menyimpulkan "Karena itu kegiatan pembiayaan dan investasi keuangan adalah termasuk kegiatan usaha namun secara pasif."

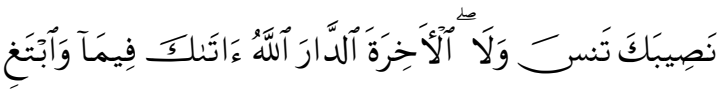

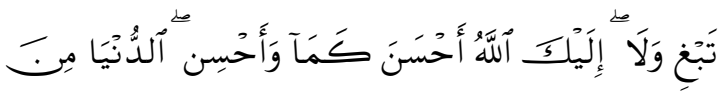

舁

"Wa'abtaghi fiimaa a watakallahhuddarolakhiroh. Walaa tansa nașiibaka minaddunyaa. Wa ahsinkamaa ahsanallahhu ilaika. Walaa tabgilfasaadan fii'lardi. innallaaha laa tuhibbulmufsidiina".

"Dan carilah pada apa yang telah dianugerahkan Allah kepadamu (kebahagiaan) negeri akhirat, dan janganlah kamu melupakan bahagianmu dari (kenikmatan) duniawi dan berbuat baiklah (kepada orang lain) sebagaimana Allah telah berbuat baik, kepadamu, dan janganlah kamu berbuat kerusakan di (muka) bumi. Sesungguhnya Allah tidak menyukai orang-orang yang berbuat kerusakan". (Q.S Al- Qashash:77)

Dari terjemahan ayat di atas, manusia telah diperintah untuk mencari kebahagiaan dan kenikmatan dunia. Secara umum, harta adalah termasuk salah satu sumber kebahagiaan dunia. Kebahagiaan dunia dan akhirat harus sama-sama berusaha didapatkan dengan porsi yang seimbang. Untuk mendapat kebahagiaan dunia tanpa melupakan kebahagiaan akhirat, manusia hendaklah berbuat baik dan menghindari perilaku merusak.

\section{Efisiensi Pasar Modal}

Harga saham di pasar merupakan harga konsensus di antara para investor, dan harga suatu saham dapat terjadi beberapa kali dalam satu hari dengan rentang lebar antara harga pasar terendah dan tertinggi (Samsul, 2006:269). Dalam pasar yang efisien, fluktuasi harga sangat tipis. Perbandingan antara harga saham di pasar dan nilai intrinsik saham mencerminkan tingkat efisiensi pasar (Samsul, 2006:270). 
Pasar modal yang efisien adalah pasar yang harga-harga sekuritasnya mampu mencerminkan semua informasi yang tersedia dengan cepat dan akurat (Nursian dan Putranto, 2004 dalam Fattimattuzzahra, 2014:16). Sehingga pasar modal dikatakan efisien bila informasinya dapat tersedia dengan cepat dan benarmencerminkan kondisi perusahaan. Sementara ada penelitian yang menitikberatkan efisiensi pasar tidak hanya pada informasi yang "fully reflect" oleh Dyckman dan Morse (1986) dalam Jogiyanto (2009:512) yang menyatakan bahwa istilah "fully reflect" juga tidak jelas. Harga dari sekuritas berubah karena adanya perubahan kepercayaan (belief) oleh investor akibat adanya informasi yang baru. Proses dari penyebaran (disseminating) informasi untuk membentuk kepercayaan yang baru terhadap harga sekuritas akan menentukan tingkat efisiensi pasar.

\section{Hipotesis Tiga Bentuk Pasar Modal yang} Efisien

Secara umum efisiensi pasar adalah hubungan harga-harga sekuritas dengan informasi Beaver dalam Hartono dalam Fatimattuzzahra, 2014:18). Lebih lanjut untuk mengelompokkan seberapa kuat efiensi di pasar Fama dalam Mohamad Samsul (2006:270) membagi efisiensi pasar dalam tiga tingkatan, yaitu:

1. The weak efficient market hypothesis

2. The semistrong efficient market hypothesis

3. The strong efficient market hypothesis
The weak efficient market hypothesis, mencermati pola pergerakan harga saham menurut setiap perubahan kondisi ekonomi dengan menganalisa harga dan volume di masa lalu. Sehingga dicermati saat terjadi kenaikan harga maka akan terjadi penurunan disaat berikutnya. Metode hipotesis ini kurang cermat dalam perkiraannya karena hanya berpedoman pada pola yang sifatnya sekuensial dan kurang mempertimbangkan pengaruh teknis yang lain sehingga kesalahan estimasi bisa mudah terjadi.

Efisiensi pasar yang setengah kuat (the semistrong efficient market hypothesis) bilamana investor menggabungkan baik analisis fumdamental maupun analisis teknikal dalam menghitung harga saham. Menurut Jogiyanto (2009:501) Pasar dikatakan efisien setengah kuat jika harga-harga sekuritas secara penuh mencerminkan (fully reflect) semua informasi yang dipublikasikan (all publicly available information) termasuk informasi yang berada di laporan-laporan kevangan perusahaan emiten.

Kemudian untuk strong efficient market hypothesis, investor menggunakan data yang lebih lengkap dari pada model hipotesis yang lain. Selain menggabungkan antara harga dan volume di masa lalu, informasi yang terpublikasi, investor juga mempertimbangkan informasi yang sifatnya lebih privat yang tidak diketahui oleh masyarakat luas.

\section{Reaksi Pasar}


Reaksi pasar mengukur kecepatan pasar untuk bereaksi dengan cepat dan benar atas sebuah informasi. Reaksi yang terjadi berupa reaksi positif dan reaksi negatif. Informasi tersebut digunakan investor untuk referensi dalam melakukan keputusan investasinya. Kecepatan reaksi pasar terkait dengan efisiensi keputusan investasi. Tandelilin $\quad(2010$ dalam Fatimatuzzahra 2014:21)

Fama dalam Husnan (2004 dalam Fatimatuzzahra 2014:21), Informasi yang relevan diklasifikasikan menjadi 3 tipe, yaitu:

1. Informasi mengenai perubahan harga di waktu yang lalu lpast price changes)

2. Informasi yang tersedia kepada publik (public information)

3. Informasi yang tersedia kepada publik maupun tidak (public and private information)

Tandelilin $\quad(2010 \quad$ dalam

Fatimatuzzahra 2014:21), reaksi yang terjadi berupa reaksi positif dan reaksi negatif. Informasi tersebut digunakan investor untuk referensi dalam melakukan keputusan investasinya. Kecepatan reaksi pasar terkait dengan efisiensi keputusan investasi.

\section{Stock Split}

Pengumuman stock split selalu menjadi fenomena yang sangat umum di kalangan perusahaan dan terus menjadi salah satu topi yang paling sedikit dipahami di bidang keuangan (Bajri dan Hasani, 2008 dalam Lancyta 2014:3).
Harga saham yang ditetapkan terlalu tinggi kurang dapat menarik minat investor untuk membeli saham. Untuk mengatasi hal tersebut seringkali perusahaan menggunakan kebijakan stock split yaitu memecah harga saham yang semula tinggi, menjadi lebih rendah nilainya.Untuk lebih jelasnya, menurut (Jogiyanto, 2009:542), harga per lembar saham baru setelah stock split adalah $1 / n$ dari harga sebelumnya.

Pemecahan saham merupakan suatu aktivitas yang dilakukan perusahaan yang telah go public dalam rangka meningkatkan jumlah saham yang beredar dengan melakukan pemecahan jumlah lembar sahamnya menjadi lebih banyak dengan tujuan agar harga sahamnya dirasa cukup murah atau terjangkau oleh investor sehingga diharapkan penjualan sahamnya bisa meningkat dan sahamnya bisa dimiliki oleh banyak investor (Brigham and Gapenski, 1994).

\section{Saham}

Kepemilikan suatu perusahaan dalam beberapa bagian dapat diperjualkan untuk menarik menarik minat calon investor, penjualan bagian dari perusahaan ini dalam bentuk saham (stock). Saham memberikan indikasi kepemilikan atas perusahaan yang mengeluarkan, para pemegang saham dapat turut menentukan arah kebijaksanaan perusahaan melalui Rapat Umum Pemegang Saham (RUPS) dan berhak atas pembagian keuntungan 
perusahaan, berupa dividen (Sutedi, 2009:3).

\section{Return Saham}

Return saham adalah tingkat keuntungan yang dinikmati oleh pemodal atas suatu investasi yang dilakukannya. Pasar sahamtidak menjanjikan suatu return yang pasti bagi para investor. Namun berharap komponen return pada saham yang memungkinkan investor meraih keuntungan adalah deviden, saham bonus, dan capital gain (Robert dalam Latifah dalam Utomo, 2015). Jogiyanto (2009:199) mengatakan bahwa return merupakan hasil yang diperoleh dari investasi. Return dapat berupa return realisasian yang sudah terjadi atau return ekspektasian yang belum terjadi tetapi yang diharapkan akan terjadi di masa mendatang.

\section{Event Study}

Penelitian ini menggunakan pendekatan event study. Dikemukakan oleh Jogiyanto (2009:536) bahwa event study merupakan studi yang mempelajari reaksi pasar terhadap suatu peristiwa (event) yang informasinya dipublikasikan sebagai suatu pengumuman. Event study dapat digunakan untuk menguji kandungan informasi (information content) dari suatu pengumuman dan dapat juga digunakan untuk menguji efisiensi pasar bentuk setengah kuat.

Jogiyanto (2009:537) menyatakan bahwa pengujian kandungan informasi dan pengujian efisiensi pasar bentuk setengah kuat merupakan dua pengujian

yang berbeda. Pengujian kandungan suatu informasi dimaksudkan untuk melihat reaksi suatu pengumuman. Jika pengumuman mengandung informasi (information content), maka diharapkan pasar akan bereaksi pada waktu pengumuman tersebut diterima oleh pasar. Reaksi pasar atas sebuah pengumuman corporate action menurut Jogiyanto (2009:537) ini diukur dengan menggunakan return sebagai nilai perubahan harga atau dengan menggunakan abnormal return.

\section{Hipotesis}

Berdasarkan perumusan masalah yang telah dijabarkan, tujuan penelitian dan landasan teori seperti yang sudah diuraikan diatas, maka diajukan hipotesis sebagai berikut :

1. Terdapat perbedaan Average Abnormal Return (AAR) sesudah terjadi stock split pada emiten saham syariah yang terdaftar di Bursa Efek Indonesia periode 2011-2014 pasca pengumuman stock split.

2. Terdapat perbedaan signifikan Cummulative Average Abnormal Return (CAAR) sesudah terjadi stock split pada emiten saham syariah yang terdaftar di Bursa Efek Indonesia periode 2011-2014 pasca pengumuman stock split

\section{Kerangka Berfikir}




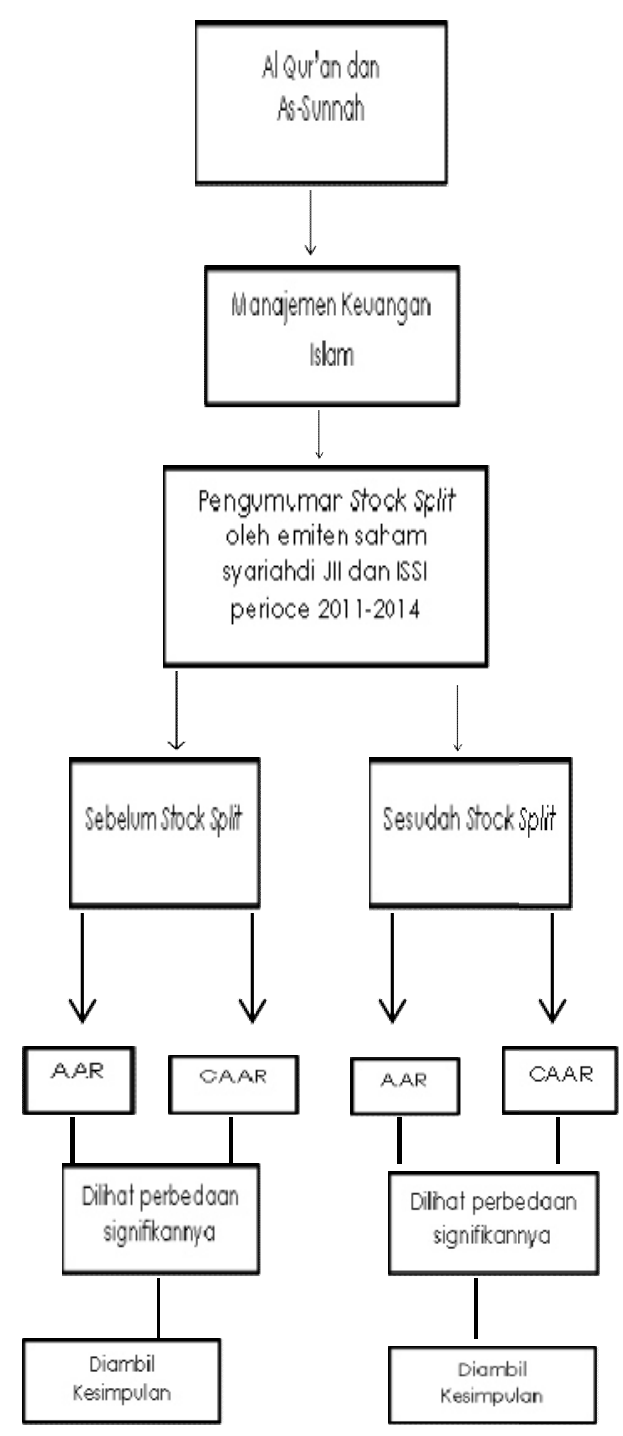

Sumber: Penulis

Gambar 1.Kerangka Berpikir

\section{METODE PENELITIAN}

Penelitian ini menggunakan jenis penelitian kuantitatif dan dengan metode event study. Sugiyono (2012:14) mengatakan bahwa tujuan dari penelitian kuantitatif adalah menemukan hubungan antarvariabel yang diuji, menguji teori, dan mencari generalisasi yang mempunyai nilai prediktif. Menurut Jogiyanto (2009:536) penelitian event study merupakan studi yang mempelajari reaksi pasar terhadap suatu peristiwa (event) yang informasinya dipublikasikan sebagai suatu pengumuman.

Peristiwa yang diambil adalah peristiwa pengumuman kebijakan perusahaan berupa stock split dan meneliti reaksi yang terjadi di pasar yaitu dengan tolok ukur adanya abnormal return. Sedangkan menurut Samsul (2006:273) event studies diartikan sebagai mempelajari pengaruh suatu peristiwa terhadap harga saham di pasar, baik pada saat peristiwa terjadi maupun beberapa saat setelah peristiwa itu terjadi.

\section{Identifikasi Variabel}

Kerlinger (1973 dalam Sugiyono, 2009:38) mengatakan bahwa variabel adalah konstruk (constructs) atau sifat yang akan dipelajari. Berdasarkan rumusan masalah dan model analisis maka penelitian ini menggunakan variabel-variabel seperti berikut ini :

1. Tanggal dan pengumuman stock split oleh perusahaan publik yang terdaftar di Jakarta Islamic Index (JII) dan Indeks Saham Syariah Indonesia (ISSI).

2. Pendapatan saham, yang terdiri dari;

a. Pendapatan aktual saham ( $\left.R_{\text {it }}\right)$

b. Pendapatan pasar saham $\left(R_{m t}\right)$

c. Pendapatan abnormal saham atau Average Abnormal Return (AAR)

d. Akumulasi pendapatan abnormal saham atau Cummulative Average Abnormal Return (CAAR)

\section{Definisi Operasional Variabel}

Anshori dan Iswati (2009:55) menyebutkan bahwa variabel dalam ilmu 
sosial banyak yang berasal dari suatu konsep yang perlu diperjelas dan diubah bentuknya sehingga dapat diukur dan dipergunakan secara operasional dalam penelitian. Maka untuk lebih memperjelas akan dijabarkan definisi operasional dari variabel-variabel yang digunakan, yaitu:

\section{Stock Split}

Peristiwa stock split merupakan objek penelitian skripsi. Untuk memperoleh informasi stock split maka penulis mencari melalui website Kustodian Sental Efek (KSEI) dan website Yahoo Finance untuk memperoleh tanggal pengumuman stock split yang dilakukan oleh perusahaanperusahaan publik yang terdaftar di Bursa Efek Indonesia periode 2011-2014.

\section{Pendapatan saham (stock return)}

Untuk memdapatkan perbedaan return saham sebagai akibat adanya reaksi pasar atas peristiwa stock split, dan berdasarkan rumus hitung yang disajikan pada bab 2, maka diperlukan beberapa komponen harga return saham antara lain:

a. Pendapatan saham aktual adalah pendapatan saham harian yang sesuai dengan kondisi yang ada oleh sebab adanya perubahan harga saham berdasarkan perhitungan selisih harga saham hari ini dengan harga saham pada hari sebelumnya

b. Expected return yaitu pendapatan saham harian yang diharapkan oleh investor. c. Abnormal Return adalah selisih antara pendapatan saham actual dengan pendapatan saham ekspektasi. Sedangkan Average Abnormal Return adalah rata-rata dari selisih antara realized return dengan expected return.

d. Cummulative Average Abnormal Return adalah hasil akhir dari jumlah seluruh Average Abnormal Return Perusahaan yang melakukan stock split.

\section{Jenis dan Sumber Data}

Jenis dan sumber data dalam penelitian menggunakan data sekunder. Data sekunder adalah adalah data yang diperoleh dari suatu organisasi atau perusahaan dalam bentuk yang sudah jadi berupa publakasi (Supranto, 2009 seperti dikutip dalam Fatimatuzzahra 2014). Data sekunder yang dipakai adalah data harga saham yang tercatat di Bursa Efek Indonesia dan melakukan stock split pada periode 2011-2014

\section{Prosedur Pengumpulan Data}

Populasi adalah wilayah generalisasi yang terdiri atas obyek atau subyek yang mempunyai kuantitas dan karakteristik tertentu yang diterapkan peneliti untuk dipelajari dan ditarik kesimpulannya (Sugiyono, 2012:80). Penelitian ini bertujuan untuk meneliti pengaruh dari pengumuman stock split terhadap pendapatan saham sehingga sampel dari penelitian ini masuk ke dalam jenis purposive sampling. Sugiyono (2012:85) mengatakan bahwa purposive 
sampling adalah teknik penentuan sampel dengan pertimbangan tertentu. Prosedur yang akan digunakan untuk memperoleh data yang dibutuhkan untuk penelitian adalah:

1. Survei kepustakaan

Survei pustaka digunakan sebagai panduan untuk memecahkan masalah dengan dukungan teori-teori yang kuat serta penelitian terdahulu dengan mengumpulkan literaturliteratur yang bersangkutan.

2. Pengumpulan data

Seluruh data yang dipakai untuk kemudian diolah dan ditarik kesimpulannya adalah data sekunder berdasarkan pengumuman stock split oleh efek yang terdaftar pada Indeks Saham Syariah Indonesia (ISSI) yang

\section{HASIL DAN PEMBAHASAN}

Pada bab ini dijelaskan tentang gambaran umum obyek penelitian yang menyangkut perusahaan emiten saham syariah yang terdaftar di Bursa Efek Indonesial yang melakukan Stock Split dari tahun dari tahun 2011 hingga tahun 2014, yang melibatkan 30 perusahaan.

Setelah ditetapkan beberapa syarat emiten saham yang akan dijadikan sampel penelitian yaitu:

\section{Pengumpulan data}

Seluruh data yang dipakai untuk kemudian diolah dan ditarik kesimpulannya adalah data sekunder berdasarkan pengumuman stock split oleh efek yang terdaftar pada Indeks Saham Syariah Indonesia (ISSI) yang diperoleh dari Bursa Efek Indonesia data dari internet.

3. Perusahaan yang masuk dalam kriteria penelitian tidak melakukan double stock split, maupun corporate action yang lain seperti pengumuman dividen, merger, akuisisi dan sejenisnya selama periode penelitian. Hal ini untuk menghindari hasil penelitian yang bias.

4. Saham perusahaan yang aktif diperdagangkan minimal 10 hari penelitian sebelum dan 10 hari sesudah tanggal pengumuman stock split untuk mengetahui seberapa besar pengaruh stock split terhadap Average Abnormal Return dan Cummulative Average Abnomal Return.

diperoleh dari Bursa Efek Indonesia data dari internet.

5. Perusahaan yang masuk dalam kriteria penelitian tidak melakukan double stock split, maupun corporate action yang lain seperti pengumuman dividen, merger, akuisisi dan sejenisnya selama periode penelitian. Hal ini untuk menghindari hasil penelitian yang bias.

6. Saham perusahaan yang aktif diperdagangkan minimal 10 hari penelitian sebelum dan 10 hari sesudah tanggal pengumuman stock split untuk mengetahui seberapa besar pengaruh stock split terhadap Average Abnormal Return dan 
Cummulative Average Abnomal Return.

Dari jumlah sebesar 30 emiten, 12 emiten melakukan corporate action lain, yaitu pembagian deviden maupun double stock spit pada periode pengamatan., sehingga dengan adanya kebijakan perusahaan diluar tujuan pengamatan tersebut dikhawatirkan akan mempengaruhi hasil penelitian dan menjadi bias. Dua emiten saham yang lain yaitu PNSE dan MTSM setelah dilakukan perhitungan menunjukkan tidak adanya pergerakan saham. Diperoleh hasil akhir bahwa emiten yang memenuhi syarat menjadi lebih kecil jumlahnya yaitu16 emiten

\section{Analisis Average Abnormal Return Pada Pengamatan Harian}

Dengan nilai Average Abnormal Return untuk emiten yang melakukan stock split secara umum cenderung memberikan hasil Average Abnormal Return yang bernilai positif. AAR yang positif berlaku pada hampir sebagian besar pada periode pengamatan, namun terdapat beberapa periode dengan AAR yang negative sehingga bisa dikatakan perolehan AAR cukup fluktuatif di sepanjang periode pengamatan.

Pada hari pengamatan pertama atau pada 50 hari sebelum peristiwa stock split ( $(-50)$ diawali oleh pendapatan abnormal rata-rata yang positif sampai pada hari berikutnya return menjadi negative pada t-49 dan sampai beberapa periode kedepan dan naik turun secara fluktuatif dengan dengan masing- masing nilai yaitu t-49 (-0.00506) t48 (-0.02691), t-41 (-0.0042), t-39 (-0.0010), t-35 (-0.00056), t-32 (-0.01128), t-29 ($0.00038), \mathrm{t}-27(-0.00796), \mathrm{t}-23(-0.0003), \mathrm{t}-21$ $(-0.0116), t-20(-0.00884), t-13(-0.00544), \mathrm{t}-$ $14(-0.0009), \mathrm{t}-13(-0.0077), \mathrm{t}-12(-0.00618), \mathrm{t}-$ 11 (-0.0013), t-9 (-0.00474), t-4 (-0.00668), †+5 (-0.01375), †+6 (-0.01398), t+7 (-0.00143), $t+8(-0.00472)$

Pendapatan rata-rata abnormal negative tersebut total terjadi pada 22 hari periode pengamatan, sehingga dari jumlah 61 hari pengamatan, 39 hari pengamatan emiten saham memperoleh pendapatan rata-rata abnormal positif dan jumlah AAR positif tersebut adalah hasil yang lebih dominan.

\section{Uji Normalitas Pada Average Abnormal}

Return.

Sebelum memulai uji hipotesis, akan dilakukan uji normalitas data. Kegunaan dari uji normalitas ini adalah untuk melakukan cek apakah data telah terdistribusi secara normal. Jenis uji normalitas yang digunakan adalah uji Kolmogorov-Smirnov. Jika data terbukti terdistribusi normal maka dapat dilanjutkan pengujian one sample t-test dan paired sample t-test. Jika data tidak terdistribusi secara normal selanjutnya akan dilakukan uji Wilcox. 
Setelah melalui tahap uji normalitas dengan uji Kolmogorov-Smirnov, hasil yang muncul adalah sebagai berikut:

Tabel 1.

Tabel Uji Normallitas AAR

\begin{tabular}{|l|l|l|}
\hline & Signifikan & Keterangan \\
\hline SAR & 0.061 & Terdistribusi Normal \\
AAR Sesudah & & Terdistribusi Normal \\
& & \\
\hline
\end{tabular}

Sumber: Data Sekunder, diolah (2015)

Hasil uji normalitas menunjukkan bahwa nilai AAR sebelum dan sesudah stock split lebih dari $5 \%$ dan sesuai dengan ketentuan, jika nilai P-value lebih besar dari $5 \%$ maka data AAR sebelum dan AAR sesudah stock split terdistribusi normal dan dapat dilanjutkan untuk pengujian selanjutnya yaitu uji one sample t-test dan paired sample t-test.

\section{Uji Normalitas Pada Cummulative Average}

\section{Abnormal Return}

Sebelum memulai uji hipotesis, akan dilakukan uji normalitas data. Kegunaan dari uji normalitas ini adalah untuk melakukan cek apakah data telah terdistribusi secara normal. Jenis uji normalitas yang digunakan adalah uji Kolmogorov-Smirnov. Jika data terbukti terdistribusi normal maka dapat dilanjutkan pengujian one sample t-test dan paired sample t-test. Jika data tidak terdistribusi secara normal selanjutnya akan dilakukan uji Wilcoxon.
Tabel 2.

Tabel Uji Normalitas CAAR

\begin{tabular}{|l|l|l|}
\hline & Signifikan & Keterangan \\
\hline $\begin{array}{l}\text { CAAR } \\
\text { Sebelum } \\
\text { CAAR } \\
\text { Sesudah }\end{array}$ & 0.008 & Terdistribusi Normal \\
& 0.958 & Terdistribusi Normal \\
\hline
\end{tabular}

Sumber: Data Sekunder, diolah (2015)

Hasil uji normalitas menunjukkan bahwa nilai CAAR sebelum stock split tdak lebih dari $5 \%$ dan sesuai dengan ketentuan, jika nilai P-value lebih kecil dari 5\% maka data CAAR sebelum tersebut tidak terdistribusi normal dan akan dilakukan uji Wilcoxon.

Tabel 3.

Tabel Uji Wilcoxon

\begin{tabular}{|c|c|}
\hline & $\begin{array}{l}\text { CAAR Sesudah - CAAR } \\
\text { Sebelum }\end{array}$ \\
\hline $\begin{array}{l}\text { Asymp. Sig. (2- } \\
\text { tailed) }\end{array}$ & $\begin{array}{l}-.968 a \\
.333\end{array}$ \\
\hline
\end{tabular}

Sumber: Data Sekunder, diolah (2015)

Setelah diuji dengan tes Wilcoxon menggunakan aplikasi SPSS ver. 16 CAAR menunjukkan hasil bahwa CAAR dapat dilanjutkan tes selanjutnya yaitu paired sample t-test karena hasil $\mathrm{p}$-value lebih dari $5 \%$ sehingga disimpulkan bahwa data telah terdistribusi normal.

\section{Uji One Sample t-Test}

Hasil uji one sample t-test menunjukkan bahwa terdapat Average Abnormal Return setelah pengumuman stock split. Dapat dicermati nilai 
probabilitasnya sebesar 0.017. Dengan nilai probabilitas sebesar yang sudah disebut, maka hasil test menunjukkan bahwa $\mathrm{H}_{0}$ diterima dan $\mathrm{H}_{1}$ ditolak. Artinya tidak terdapat AAR pada pengujian atas reaksi pasar atas stock split pada emiten saham syariah yang terdaftar di Bursa Efek Indonesia periode 2011-2014.

\section{Uji Paired Sample t-Test}

Diketahui dari hasil pengujian paired sample t-test untuk menunjukkan bahwa Average Abnormal Return sebelum dan sesudah pengumuman stock split memiliki nilai probabilitas 0.732 yang berarti nilai probabilitasnya lebih besar dari nilai a yang telah ditetapkan yakni $(a)=5 \%$. Hasil uji berdasarkan SPSS ver. 16 menyatakan bahwa $\mathrm{H}_{0}$ diterima dan $\mathrm{H}_{1}$ ditolak dengan penjelasan bahwa tidak terdapat perbedaan yang signifikan atas Average Abnormal Return sebelum dan sesudah stock split.

\section{SIMPULAN}

Berdasarkan hasil analisis
pembahasan, maka dapat ditarik
kesimpulan penelitian Reaksi Pasar
Terhadap Stock Split dan Return Saham
(Studi Pada Emiten yang Terdaftar Di JII
dan ISSI periode 2011-2014), dapat ditarik
kesimpulan sebagai berikut:
1. Terdapat Average Abnormal Return
setelah pengumuman stock split,
namun nilai AAR sebelum dan
setelahnya tidak ada perbedaan
secara signifikan sebelum dan
sesudah stock split.

2. Nilai Cummulative Average Abnormal Return berbeda secara signifikan pada periode pengamatan sebelum stock split dan setelah pengumuman stock split.

\section{DAFTAR PUSTAKA}

Anshori, M. dan Iswati. (2009). Buku Ajar Metodologi Penelitian Kuantitatif. Surabaya: Airlangga University Press.

Bodie, Kane. and Marcus. (2005). Investment. Sixth Edition. New York: Mc Graw Hill.

Chapra, Umer. M. (2000). Sistem Moneter Islam. Jakarta: Gema Insani Press.

Copeland, T. E. (1988). Manajemen Keuangan. Jilid I, Edisi Kedelapan. Erlangga.

Damayanty, Wanvanna. N. (2011). Abnormal Return Dan Volume Perdagangan Saham Sebelum Dan Sesudah Stock Split Di Bursa Efek Indonesia (BEI). Surabaya Fakultas Ekonomi dan Bisnis Universitas Airlangga: Skirpsi tidak diterbitkan.

Elton, E. J. (1995). Modern Portofolio Theory and Investment Analysis. New York: John Wiley \& Sons.

Emilia, Talita. C. (2011). Pengaruh Publikasi Stock Split Terhadap Harga Saham, Volume Perdagangan, dan Return Saham Pada Perusahaan go Public Yang Terdaftar Di BEl Pada Tahun 20062009. Surabaya: Universitas Airlangga. Fatimatuzzahra, Vita. (2014). Reaksi Pasar Atas Penerbitan Sukuk Studi Pada 
Emiten Saham Penerbit Sukuk Periode 2008-2012. Surabaya Fakultas Ekonomi dan Bisnis Universitas Airlangga: Skripsi tidak diterbitkan.

Ghazaly dkk. (2010). Fiqh Muamalat. Jakarta. Penerbit Kencana

Hartiar, Y. D. (2006). Pengaruh Peristiwa Bom Bali II Terhadap Harga Saham (Studi Kasus LQ-45 di BEJ). Surabaya Fakultas Ekonomi dan Bisnis Universitas Airlangga: Skripsi tidak diterbitkan.

Huda, Nurul. d. (2007). Investasi Pada Pasar Modal Syariah. Jakarta: Kencana. Husnan, Suad. (1994). Dasar-dasar Teori Portofolio dan Analisis Sekuritas. Yogyakarta: Unit Penerbit dan Percatakan AMP YKPN.

Jogiyanto, H. M. (2009). Teori Portofolio dan Analisis Investasi. Edisi Keenam. Yogyakarta: BPFE Universitas Gajah Mada.

Kumar, S. S. (2011). Impact of Stock Split Announcement on Stock Price, Vol.1, No. 1. Review of Management, 15-26.

Lancyta, Sarah. (2014). Reaksi Investor Dan Volatilitas Pasar Pada Pengumuman Pemecahan Saham (Stock Split) Di Bursa Efek Indonesia Tahun 2007-2012. Surabaya Fakultas Ekonomi dan Bisnis Universitas Airlangga: Skripsi tidak diterbitkan.

Nusantara, A. (2004, Agustus ). Pasar Modal Islami Antara Harapan dan Kenyataan. Vol. 3, No. 2.

Pontjowinoto, I. P. (2003). Prinsip Syariah di Pasar Modal. Jakarta: Modal Publications.
Ryandono, Muhammad Nafik. (2009). Bursa Efek dan Investasi Syariah. Penerbit Serambi

Samsul, Mohamad. (2006). Pasar Modal Dan Manajemen Portofolio. Jakarta: Penerbit Erlangga.

Saputra, E. F. (2009). Perbedaan Likuiditas Dan Return Saham Sebelum dan Sesudah Pengumuman Stock Split Pada Perusahaan-Perusahaan Yang Terdaftar Di Bursa Efek Indonesia Tahun 2004-2007. Surabaya Fakultas Ekonomi dan Bisnis Universitas Airlangga: Skripsi tidak diterbitkan.

Sharpe, W. F. (1995). Investasi. (Edisi Bahasa Indonesia). Vol.1. Jakarta: Prenhallindo.

Suta, I. Putu. (2000). Menuju Pasar Modal Modern. Jakarta: SAD SRIA BHAKTI.

Sutedi, A. (2009). Segi-segi Hukum Pasar Modal. Bogor: Ghalia Indonesia.

Sutedi, A. S. (2011). Pasar Modal Syariah, Sarana Investasi Keuangan Berdasarkan Prinsip Syariah. Jakarta: Sinar Grafika.

Tandelilin, E. (2001). Analisis Investasi dan Manajemen Portofolio. Yogykarta: BPFE. Tarjamah Al-Qur'an Al-Hakim. Bahreisy, Salim dan Bahreisy, Abdullah. 2001.Surabaya. CV Sahabat IImu

Van Horne, J. C. (2009). Fundamentals of Financial Management (Prinsip-prinsip Manajemen Kevangan). Jakarta: Salemba Empat. 